\title{
PRIMEROS PROMOTORES DE LA IDEA DE HISPANIDAD: DARÍO, MENÉNDEZ PELAYO, VALERA, ALTAMIRA Y UNAMUNO
}

\author{
First promoters of the idea of spanishness: \\ Darío, Menéndez Pelayo, Valera, Altamira and Unamuno
}

Ronald Campos López*

\begin{abstract}
RESUMEN
Se analiza el contexto de España y América desde 1492 hasta la crisis finisecular española, con tal de observar los orígenes y evolución de la idea de hispanidad y su expresión concreta en el pensamiento y escritos de sus primeros promotores: Rubén Darío, Marcelino Menéndez Pelayo, Juan Valera, Rafael Altamira y Miguel de Unamuno.

Palabras clave: Hispanidad, Rubén Darío, Marcelino Menéndez Pelayo, Juan Valera, Rafael Altamira, Miguel de Unamuno.
\end{abstract}

\begin{abstract}
The context of Spain and America since 1492 to Spanish finisecular crisis is analyzed, to note Spanishness idea beginning and evolution and it concretized expression in the thought and texts of her first promoters: Rubén Darío, Marcelino Menéndez Pelayo, Juan Valera, Rafael Altamira y Miguel de Unamuno.

Key Words: Spanishness, Rubén Darío, Marcelino Menéndez Pelayo, Juan Valera, Rafael Altamira, Miguel de Unamuno.
\end{abstract}

Poeta costarricense, estudiante de doctorado en Español: Lingüística, Literatura y Comunicación, en la Universidad de Valladolid.

Correo electrónico: ronaldc184@yahoo.com

Recepción: 04/02/14. Aceptación: 27/10/14. 


\section{Aparición del término "hispanidad"}

Las ideas de América generadas durante el siglo XIX prepararán las del XX. Por eso, aunque las coyunturas conducentes a hablar sobre hispanidad son decimonónicas, el término como se entiende actualmente aparece casi un siglo después, pese a sus huellas históricas.

Probablemente, hispanitas (Vizcarra 1944) e hispanitatem (Giménez Caballero 1963) fueron términos usados en el siglo I por los romanos para nombrar los giros hispánicos del latín de Quintiliano. Durante el Renacimiento, Filelfo (Giménez Caballero 1963) y Alexo Vanegas (Vizcarra 1944, Giménez Caballero 1963) retomaron el vocablo con igual sentido. En las ediciones de 1817 y 1925 del Diccionario de la Academia, la entrada "hispanidad" dirigía a "hispanismo", la cual denotaba: "Modo de hablar peculiar de la lengua española, que se aparta de las reglas comunes de la Gramática. Idiotismus hispanicus" (Vizcarra 1944: §6). Siguiendo esta acepción, Álvarez (1950), Giménez Caballero (1963), Chávez (1966) y Roberts (2004) observaron que Unamuno empleó dicho vocablo primeramente, al referirse al factor lingüístico de España e Hispanoamérica. Sin embargo, en un artículo publicado en 1909, Unamuno ya había usado "hispanidad" para mostrar "aquellas cualidades espirituales, aquella fisonomía moral, mental, ética, estética, religiosa" (Unamuno, Obra... 543) de los pueblos hispánicos. Si bien hasta ese momento del siglo XX el sentido gramatical del concepto poco había variado, inclusive en Unamuno, el significado ampliado por el salmantino pregona el matiz valorado y enfatizado por Vizcarra en 1926, quien a partir de las voces "humanidad" y "cristiandad" propuso analógicamente "hispanidad", la cual denotaba: "en primer lugar, el conjunto de todos los pueblos de cultura y origen hispánico diseminados por Europa, América, África y Oceanía; expresa, en segundo lugar, el conjunto de cualidades que distinguen del resto de las naciones del mundo a los pueblos de estirpe y cultura hispánica" (Vizcarra 1944: §17). Aunque autores como Maeztu (1931, 1934), Gomá (1934), Vallejo (1937), Mayán (1943), Forment (2008) y Hernández (2012) atribuyeron la creación del término a Vizcarra, él mismo aclaró en 1944 que no lo creó, sino que lo lanzó con otra acepción. Como resultado de la nueva acepción dada por Vizcarra, en 1939, en la edición decimosexta del susodicho diccionario, se advirtió: "Hispanidad, f. Carácter genérico de todos los pueblos de lengua y cultura española. 2. ant. Hispanismo" (Vizcarra 1944: §20). Según Giménez Caballero (1963), este nuevo significado se consolidó, además, gracias a los trabajos del Instituto de Cultura Hispánica a partir de la década de los 50 y los de las Academias de la Lengua en sus congresos de México (1952), Madrid (1956) y Bogotá (1960). Finalmente, desde la vigésima segunda hasta la actual (2014) del Diccionario de la Real Academia Española, "hispanidad" denota: "1. Carácter genérico de todos los pueblos de lengua y cultura hispánica. 2. f. Conjunto y comunidad de los pueblos hispánicos. 3. f. ant. hispanismo" (RAE 2001).

$\mathrm{Si}$ estas son las cargas semánticas del término en los siglos XX y XXI, ¿cuáles fueron sus cimientos coloniales y las fuerzas decimonónicas que nutrieron y promovieron su forma concreta?

\section{Marco referencial: Desde 1492 hasta la crisis de 1898}

El ser hispánico del siglo XVI creó las realidades históricas del Nuevo Mundo y su identidad heterogénea desde 1492 hasta 1824 con base en: 1) la espiritualidad del humanismo español y la evangelización cristiana, 2) el código jurídico y humanístico de las Leyes de Indias, 3) la dirección del Estado monárquico sobre la experiencia política americana. Sobre estos cimientos, a lo largo de los tres siglos de convivencia y mutua cesión cultural, se originó la hispanidad.

Pese a la unidad lingüística, religiosa, cultural, urbanística y política de la Corona con las provincias americanas, los problemas 
de comunicación, una administración ineficaz, la corrupción, un inadecuado desarrollo económico en los territorios americanos, la subordinación y el tratamiento injusto de los indios y mestizos, así como el impedimento de la ortodoxia dominante española en relación con el desarrollo intelectual en América en el nivel de Francia e Inglaterra condujeron a la etapa romántica del proceso de independencia (Juan y Ulloa 1918, Marías 1992, Zuleta 2000, Hernández 2012). Sin embargo, las influencias ilustradas, la escisión geográfica, política y republicanismos no impidieron que tales provincias mantuvieran adhesión intelectual y sentimental con la tradición hispánica (Kosling 1955, Zuleta 2000). ¿Por qué? Durante la Colonia, el proceso misionero de la espiritualidad cristiana penetró en un ser americano de raíces indígenas e ibéricas, de manera que le permitió, sin importar sus variantes mestiza, mulata o criolla, su integración e identidad con los valores de la hispanidad, la vida comunitaria y el ordenamiento urbanístico; por eso, a pesar de los cambios políticos, no se dio una separación espiritual, pues la religión, la lengua, la historia, las costumbres y los usos siguieron siendo comunes y subsistieron ante su desdén y rechazo violento posterior a las guerras de Independencia (Kosling 1955, Hernández 2012).

Por esta vía se llegó a los planteamientos decimonónicos de la hispanidad.

A pesar de que ente 1810 y 1821 la emancipación y creación de las nuevas repúblicas no reflejaron preocupación en la conciencia nacional ni fueron tema de discusión (Kosling 1955, Fernández 1957, Almagro, s.f., citado en Lago 1997), España sufrió una desinternacionalización, justamente por dichas guerras, levantamientos e intervenciones de Estados Unidos (Hernández 2012). A inicios del reinado de Isabel II (1833-1868), se experimentó una crisis económica y, para solucionarla, la burguesía y negociantes españoles reinstalaron "una imagen del imperio acuñada en el siglo XVIII: América como mercado comercial y como factor en la política de defensa de las dos posiciones [ideológicas del momento]" (Zuleta 2000: 71). De este modo, comienza una primera formulación de panhispanismo al considerar a América parte de una comunidad hispánica y una tradición cultural e histórica. Sin embargo, dicho objetivo no se cumplió por causa de la intervención de España en los asuntos internos de Perú, Bolivia, Chile, Argentina y México, entre 1842 y 1847; en consecuencia, se atacaron colectividades españolas en México, Perú y Cuba; la "leyenda negra" acrecentó el desprestigio, ignorancia y distorsión de lo hispánico; el interés en potencias como Francia, Inglaterra, Alemania y Estados Unidos aumentó (Zuleta 2000).

Otra posibilidad clave, empero, se develaba. Hacia 1840, en el ambiente español circulaba el concepto de "raza" despojado del exclusivismo biológico y la superioridad evolutiva étnica, por influencia del darwinismo social (Litvak 1980, Zuleta 2000, Álvarez 2002). Tal concepto se comenzó a perfilar como mito o elemento esencial para una comunidad lingüística, religiosa o nacional hispánica opuesta al estilo de vida y cultura de los Estados Unidos (Van Aken 1959, Litvak 1980). "Raza", pues, "equivalía a cultura, y se empleaba como símbolo de los lazos tradicionales que ligaban a España con Hispanoamérica" (Zuleta 2000: 73).

A fin de imponer una imagen fraterna y comprensiva de América (Zuleta 2000), a partir de los 50 se crearon y divulgaron periódicos, como El Museo Universal (1857-1869) (Zuleta 2000), y revistas, por ejemplo, La Ilustración Española y Americana (1869-1921) (Palenque 1990, Celma 1991, Zuleta 2000). A esto se aúnan las labores de académicos en lengua e historia. La Real Academia Española, verbigracia, fundó filiales en Ecuador (1874), México (1875) y El Salvador (1876). Esta proyección fue apoyada por humanistas y fieles a la cultura hispánica, como: Andrés Bello, Miguel Antonio Caro y Rufino José Cuervo.

Como se colige, a mediados del siglo XIX se generó un cambio de actitud de España respecto de Hispanoamérica y viceversa, debido a la preocupación por el concepto de raza, las publicaciones periódicas y las funciones de las Reales Academias de la Lengua e Historia 
sobre temas culturales, filológicos, lingüísticos, económicos, religiosos, científicos e históricos.

Estas relaciones progresaron junto al panlatinismo europeo: Frente a los avances materiales, científicos, industriales, artísticos e intelectuales de los países nórdicos hacia 1870, Italia, España y Francia se enfrentaron al individualismo, protestantismo, mercantilismo y nordicismo, reforzando su política, técnicas e intelectualidad para recuperar su rol de guías del mundo occidental en nombre de su civilización heredada de Roma (Litvak 1980); de ahí se volvieron elementos esenciales para el progreso el autoritarismo y la religión católica. Tal reaccionaria idea se extendió a Rumania (1879) y, posteriormente, Portugal, Suiza, Canadá, Brasil y otras naciones americanas. En su apoyo, circularon en Europa y América publicaciones como: La Raza Latina (18741884), Fratilia Intru Dreptate (1882) y Revue des Deux Mondes (1894) (Litvak 1980, Zuleta 2000). Sin embargo, en 1897 el panlatinismo decayó, debido al pesimismo generado por la guerra española en Cuba y las disensiones entre felibres (Litvak 1980). Pese al declive, la polémica entre latinos y anglosajones generó una actitud europeizante prolatina, el desencadenamiento de actitudes nacionalistas, alentadoras de estudios psicológicos, sociológicos, antropológicos e históricos (Litvak 1980). Como resultado, la preocupación por el concepto de raza se acrecentó en Europa (Álvarez 1895).

Los esfuerzos y efectos del panlatinismo iban fomentando simultáneamente en España el período de la Restauración (1875-1902), en que se asentaron los pilares que se reflejarán en la idea nacionalista de hispanidad a principios del siglo XX: el patriotismo, el recuerdo del imperio colonial como fundamento de la grandeza nacional, los intereses por la lengua castellana, el cristianismo y la doctrina racista, frente a la invasión revolucionaria, el racionalismo moderno, las religiones musulmana, judía, el protestantismo y, más tarde, contra el capitalismo estadounidense y el comunismo materialista soviético (Álvarez 2002). En esta época, asimismo, el concepto de expansión imperial territorial motivó las pretensiones de conseguir la Unión o Federación Ibérica (proyecto que se venía gestando desde la anexión de reinos durante la Edad Media y se proclamó hasta 1873), ante Italia, Alemania, Gran Bretaña (primera potencia mundial de la época) y Francia (había desplazado a España culturalmente ante las repúblicas americanas). Debido al poco alcance y fallos de dicha unión, Portugal abandonó el proyecto y España se dedicó a celebrar el catolicismo, un "nacionalismo hipersensible" (Álvarez 2002: 17) y un plan educativo encargado de fabricar sujetos católicos (Balmes 1925, Álvarez 2002).

Lainadaptación de España a la modernidad y la pérdida de sus últimas colonias ultramarinas colapsaron este patriotismo, no obstante, y suscitó un sentimiento de degeneración social (Álvarez 2002). En esta coyuntura nació el movimiento hispanoamericanista, componente dinámico para la idea rotunda de hispanidad. Entre 1880 y 1900, se conmemoraron, entre otros, el Congreso Pedagógico HispanoPortugués-Americano y el IV Centenario del Descubrimiento de América. Igualmente, se crearon y difundieron revistas y periódicos varios, entre ellos: La España Moderna (1889-1914) y la Revista de Historia y Literaturas Españolas, Portuguesas e Hispanoamericanas (1895). Se fundó el Museo y Biblioteca de Ultramar (1888). Se rediscutieron las ideas confederativas de Simón Bolívar y la Restauración. En resumen, el acercamiento hispanoamericanista fue posible por: 1) el imperialismo amenazador de Estados Unidos, 2) la concomitancia cultural entre las naciones hispanohablantes y 3) la tentativa de una confederación.

¿Repercutió negativamente la crisis del 98 sobre las relaciones hispanoamericanistas? Lo cierto es que no: Hispanoamérica, conmovida por el desastre, manifestó su solidaridad con España y esta aminoró los últimos rastros de indiferencia. Surgió así "por primera vez desde la independencia, un común anhelo de unidad, ya no política, sino espiritual y cultural" (Fogelquist 1958: 25).

Si bien la Generación del 98 buscó las causas de la crisis in interiore Hispaniae, también atendió el tema de la hispanidad, entendiéndola 
como: 1) proyecto de clases, donde una clase social hegemónica, capitalmente burguesa y criolla, españoles por generación, desconocía o evitaba reconocer al negro, al indio o al mestizo; 2) una sociedad mestiza, donde el discurso devaluatorio del mestizo, el indio y el negro quedaba ausente por completo (Rojas 1997). En todo caso, la Generación del 98 y su modernismo permitieron a los literatos de ambas partes el intercambio de la preocupación por la crisis finisecular y la idea de América en la opinión pública e intelectual española, a favor siempre de una renovación del espíritu hispánico (Alvar 1999, Hernández 2012). Asimismo, el asunto entre Panamá y Estados Unidos por el canal en 1903 estimuló el sentimiento de fraternidad, aun en los escritores modernistas más cosmopolitas, como Darío.

Esta eclosión de intelectualidad, literatura, relaciones culturales y políticas impulsó los discursos y movimientos regeneracionistas, que desde antes del 98 se sentían, pero se potenciaron sustentados en una política conservadora y católica radical (Hernández 2012).

En fin, entiéndase que desde los movimientos hispanoamericanistas hasta los regeneracionistas, se expusieron conceptos y argumentos fundamentales para la idea concreta de hispanidad. Por ello, es necesario un ahondamiento en los principios de Rubén Darío, Marcelino Menéndez Pelayo, Juan Valera, Rafael Altamira y Miguel de Unamuno.

\section{Primeros promotores de la hispanidad}

\subsection{Rubén Darío}

De los prólogos para sus poemarios y su poesía misma se desprende la idea de hispanidad. Darío expresó, desde la "Introducción" de Epístolas y poemas (1885) hasta el "Prefacio" de Cantos de vida y esperanza (1905), siempre un optimismo en el sentido poético que lo llevó a considerar el idealismo espiritual, con el fin de revelar la armonía, la verdad, lo humano y lo sagrado como auténticos valores artísticos, afines al "epos hispanida" de la esperanza y la vida como ya vio Giménez Caballero (1965). Justamente, en la "Introducción" de Epístolas y poemas, al respecto dice: "que en la miel de la armonía/ dé el filtro de la verdad;/ que muestre a la humanidad/ lo luminoso y lo santo;/y que se escuche su canto/ por toda la eternidad" (Darío 2007: 499).

Debido a su introspección y retrospección del tiempo y el espacio, la búsqueda de lo universal y su pertenencia a ello, manifestó un sentimiento de humanidad sin arraigarse a ningún nacionalismo o patria particular. Si bien dedicó versos y prosas a Nicaragua, Argentina, Chile y Francia, y aunque su patria summa - por influencia del panlatinismo- fue lo helénico, latino, hispánico, americano, francés ("Bebiendo la esparcida savia francesa/ con nuestra boca indígena semiespañola,/ día a día cantamos la Marsellesa/ para acabar danzando la Carmañola", Darío 2007: 332); lo universal afincado en su espíritu que convirtió en estética humanista (Salinas 1975), en ningún otro caso evidenció profundamente lo social e histórico como en el caso de España. De ahí que vivió poética, política, social y humanísticamente su herencia hispánica. Lo conmovieron, por ejemplo, la crisis del 98 y la autocrítica de lo español que esta suscitó; así como la visita del rey Óscar de Suecia y su saludo: "Vive l'Espagne!", expresión que motivó la génesis de "Al rey Óscar". Su poesía, pues, impactó a tal punto el ámbito cultural y literario español que se publicaban textos suyos y críticas en torno a estos en casi todas las revistas y periódicos de la época. Celma (1991), por ejemplo, puntualiza la presencia de textos de Darío en La Ilustración Española y Americana (Palenque [1990] también corrobora dicha presencia en esta revista), Madrid Cómico (1880), La España Moderna, Vida Nueva (1898-1900); La Vida Literaria (1899), publicación semanal; Revista Nueva (1899), Electra (1901), Helios (1903-1904), Alma Española, La República de las Letras (1905), El Nuevo Mercurio (1907), Renacimiento (1907) y Hojas Selectas (1902-1920), revista mensual. 
Su patria madre, de raza, lengua y religión era España; Francia, la patria universal. Darío creyó en la necesidad de que las nuevas repúblicas independientes americanas rebuscaran en su alma mater el amparo espiritual y la orientación para su propio surgimiento exitoso; así como el hecho de auxiliarla en su crisis: "hacia el país maternal que el alma americana —americanoespañolaha de saludar siempre con respeto, ha de querer con cariño hondo. Porque si ya no es la antigua poderosa, la dominadora imperial, amarla el doble; y si está herida, tender a ella mucho más" (Darío 1950: 17). Por eso, criticó, en 1901, “el alejamiento de la madre patria del coro de las dieciséis Repúblicas hermanas" (Darío 1950: 50). Los versos de "Salutación del optimista", en que se alude cuando Roma amamantó a Hispania ("¿Quién dirá que las savias dormidas/ No despiertan entonces en el tronco del roble gigante/ Bajo el cual se exprimió la ubre de la loba romana?", Darío 2007: 249), resultan significativos en esta dirección, pues en ese momento era España quien debía nutrir a sus filiares pueblos americanos. En sintonía con esto, Zorrilla de San Martín afirmó: "El pueblo que nos dio su sangre y su lengua y su fe, debe darnos aire, luz, estímulo. En el mundo moral, como en el físico, la lactancia es la continuación obligada de la obra de la generación" (citado en Rojas 1997: 176). El reclamo protector y nutricio se traducía en el reencuentro hospitalario de la sangre y la solidaridad: "Un continente y otro renovando las viejas prosapias,/ En espíritus unidos, en espíritu y ansias y lengua" (Darío 2007: 250). De ahí que Darío encontró al "abuelo español de barba blanca [que] me enseña una serie de retratos ilustres" (Darío 2007: 158); retomó de la progenie hispana figuras de valor histórico, político, social, artístico y literario como: el Cid, Isabel la Católica, Colón, Velázquez, Cortés, Quevedo, Tirso, entre otros; valoró lo hispanomusulmán y sefardí ; llegó a personificar poéticamente en don Quijote el "Santo patrono de la causa eterna del idealismo (...) y la heroicidad moral, virtudes de universal circulación" (Salinas 1975: 267 y 226) y le exhortó a este "Noble peregrino de los peregrinos" que intercediera por el espíritu hispánico ante la falta de vitalidad, la pérdida de la fe, las congojas y tristezas de "los superhombres de Nietzsche", el academicismo doctrinario anquilosado, el pesimismo, la "canallocracia" y la deshonra, entre otros vicios.

Para Darío, en síntesis, el porvenir de América española estaría marcado según la menor emancipación que tuviera con respecto a la influencia intelectual, ética, artística y espiritual de España y, por antonomasia, la influencia civilizadora de Roma.

Pese a todo, rechazó a la España dogmática políticamente. En realidad, él "nunca fue, estrictamente hablando, un pensador político y no tuvo un programa ideológico concreto (...) Prefiere la poesía a la política" (Acereda 2000: $\S 3)$. En el último párrafo del "Prefacio" de Cantos de vida y esperanza, expresó su actitud cosmopolita y unificadora de la ideología y poética hispanoamericanas (él se percató de que su "movimiento de libertad" triunfó tanto en América como en España); el afán de protesta fue inferior a sus esfuerzos por alcanzar una estética bella, ilustre y noble. Su conciencia se dirigió a rescatar más bien la herencia espiritual y social hispánica de España e América frente a los excesos de materialismo, democracia, poder económico y político de Estados Unidos (Allen 1967), su racismo (Jackson 1967) y carencia de valores religiosos como los del cristianismo de América española . Él no se oponía al sajonismo, estaba contra la falta de respeto y el acecho de la libertad: "Eres los Estados Unidos,/ Eres el futuro invasor/ De la América ingenua que tiene sangre indígena,/ Que aún reza a Jesucristo y aún habla en español" (Darío 2007: 258). Por eso, afirmó Salinas: "En su espíritu no hay odio, sí temor” (1975: 244). Esta preocupación por que la cultura latina e hispanoamericana cayeran ante los anglosajones se expresa en "Los cisnes": "¿Seremos entregados a los bárbaros fieros/ ¿Tantos millones de hombres hablaremos inglés?" (Darío 2007: 269).

La identidad de América española, pues, para Darío constituyó una esencia, cuyo origen procedía del nacimiento y fortalecimiento de la hispanitas peninsular. Lo caballeresco, noble, heroico, católico y castellano se reformulaban, 
se imponían y debían aceptarse, ya que sobre este ethos Hispanoamérica habría de erigir su mestizaje, rechazando lo sajón como amenaza de la hispanidad, y aun de la latinidad, puesto que por razones históricas los hechos se reiteraban: así como las periferias del Imperium Romanum fueron amenazadas por los bárbaros, así las herederas latinas lo eran en ese momento por el bloque anglosajón y germánico (Litvak 1980, Hurtado 2001).

\begin{abstract}
Ínclitas razas ubérrimas, sangre de Hispania fecunda,/ Espíritus fraternos, luminosas almas, ¡salve!" (Darío 2007: 249). Estos dos primeros versos de "Salutación del optimista" revelan una epifanía del porvenir, progreso y éxito, en tanto se es hijo de la hispanidad, su conocimiento, su verdad, ética, solidaridad y espiritualidad. Darío extendió ese modo de sentir la hispanidad a todos los rincones españoles e hispanoamericanos, unificados por el ideal espiritual común: "Únanse, brillen, secúndense, tantos vigores dispersos; / Formen todos un solo haz de energía ecuménica./ Sangre de Hispania fecunda, sólidas, ínclitas razas,/ Muestren los dones pretéritos que fueron antaño su triunfo (Darío 2007: 250).
\end{abstract}

En consecuencia, reprochó el pesimismo y la escisión: "Abominad la boca que predice desgracias eternas,/ Abominad los ojos que ven sólo zodíacos funestos,/ Abominad las manos que apedrean las ruinas ilustres,/ $\mathrm{O}$ que la tea empuñan o la daga suicida (...) ¿Quién será el pusilánime que al vigor español niegue músculos/ Y que al alma española juzgase áptera y ciega y tullida?" (Darío 2007: 249250). Apeló entusiasta y optimista a la unión de los dos continentes sin desmentir ni negar sus pasados, más bien encontrando en ellos su riqueza, grandiosidad y libertad: "La latina estirpe verá la gran alba futura,/ En un trueno de música gloriosa, millones de labios/ Saludarán la espléndida luz que vendrá del Oriente,/ Oriente augusto en donde todo lo cambia y renueva/ La eternidad de Dios, la actividad infinita./ $\mathrm{Y}$ así sea Esperanza la visión permanente en nosotros, ¡Ínclitas razas ubérrimas, sangre de Hispania fecunda!” (Darío 2007: 250). Insistió en la genealogía hispana, mestiza y grecolatina , así como en los vínculos psicobiológicos
(Lombardi 1984). En fin, solicitó un equilibrio ecléctico de signos socioculturales e históricos y símbolos de ambas latitudes trasatlánticas. España y América española debían aceptar sus palimpsestos, pues de la sanación y hermandad de los hispanos dependería el resurgimiento de la hispanidad.

Hispanoamérica fue para Darío el sustrato poético de flora, fauna, geografía, historia y personajes ilustres (Suárez 1968); esa América de grandeza y lenguajes pasados, filosofías y políticas propias, posteriormente alfabetizada por la Península, vinculada a esta por la empresa colombina: "Mas la América nuestra, que tenía poetas/ Desde los tiempos de Netzahualcoyotl,/ Que ha guardado las huellas de los pies del gran Baco,/ Que el alfabeto pánico en un tiempo aprendió" (Darío 2007: 259).

A pesar de los discursos de la época y el desdén por lo americano y precolombino, el mestizaje fue fundamental para Darío, pues invitaba a "una reflexión marcada por tres rasgos: el estético, el político y el pedagógico. En el pensamiento se encontraría la unidad [...dado que se...] establecerá una estrecha relación entre filosofía, identidad y lenguaje" (Rojas 1997: 179-180). Su concepto de mestizaje se observa en los siguientes fragmentos de los poemas "Raza": "Juntos alientan vástagos/ de beatos e hijos/ de encomendados, con/ los que tienen el signo/ de descender de esclavos africanos,/ o de soberbios indios" (Darío 2007: 414); y "A Colón", respectivamente: "Cuando en vientre de América cayó semilla/ de la raza de hierro que fue de España,/ mezcló su fuerza heroica la gran Castilla/ con la fuerza del indio de la montaña" (Darío 2007: 333).

El vértice de la religión es fundamental para completar la anterior triada. Pero más que la inquisitiva religión católica del progreso hispánico imperial, Darío entendió la creencia en Dios -aunque siempre dentro de "un catolicismo tradicionalista y conservador" (Rojas 1997: 171) - como la fuente de la auténtica espiritualidad que garantizaría el bienestar social, político, filosófico, moral y económico 
fundacional de las naciones americanas. "La hispanidad sólo podía salvarse volviendo al catolicismo espiritualista" (Rojas 1997: 171).

Este es el ideal dariano que llegó a concretarse rotundamente en su poesía, pero más a lo largo de Cantos de vida y esperanza. Más que "hispanidad", él lo denominó "hispanismo", respondiendo a los movimientos hispanoamericanistas de la época. En todo caso, allende la cuestión nominal, Darío, al definirse como “"español de América y americano de España' (...) afirma de nuevo el anhelo (...) de alzarse sobre las patrias con lindes geográficos e históricos, en busca de otra especie de anterior patria común; ni lo americano quita de sentirse español en España, ni lo español obsta a la conciencia de ser americano" (Salinas 1975: 41).

En síntesis, en su poesía y prosa, Darío $(1950,2003,2007)$ se identificó social e históricamente con España y declaró poéticamente el hispanismo (la hispanidad) como el idealismo espiritual, producto de la herencia cultural, religiosa y lingüística del Imperio; raíz común que obligaba a las naciones americanas y España a religarse, ante la decadencia de esta en 1898, a través de la literatura, la espiritualidad católica, la raza hispánica y latina, la vida social en términos humanistas, prescindiendo de los límites geográficos, nacionalismos y dogmatismos políticos; valorando, además, el pasado musulmán, sefardí, precolombino, mestizo y criollo, así como la reflexión estética, política y pedagógica que estos legados implicaban. España debía ser, para las incipientes repúblicas, según Darío, amparo, orientación espiritual y ética, ya que aquella provenía de la civilización latina y, por ende, era continuadora de los ideales del panlatinismo frente al protestantismo, racismo y los excesos del materialismo, la democracia, el poder económico y político de Estados Unidos. El auténtico ethos o modo de ser hispánico se basó, en consecuencia, en lo caballeresco, noble, heroico, católico y castellano: bases del espíritu común y la identidad hispanoamericana. De la fraternidad y la sanación de las relaciones entre España y América española, dependía, pues, para Darío, la hispanidad.

\subsection{Marcelino Menéndez Pelayo}

Menéndez Pelayo planteó su ideología nacionalista en general, partiendo de que el carácter español comenzó a acentuarse en la cristianización, latinización y romanización de Hispania; hechos que condujeron, en su opinión, a la unidad nacional, legislativa, lingüística, teológica, literaria, filosófica y artística de España y su raza, la cual incluía a los lusitanos y otros habitantes históricos de la península, excepto judíos y musulmanes.

$\mathrm{Su}$ idea sobre la hispanidad se puede interpretar a partir de "Al lector" y "Advertencias generales" de su Historia de la poesía hispanoamericana (1911), "primera historia de la producción poética americana, enmarcada en el contexto cultural y estético de cada uno de los países, desde la época virreinal hasta mediados del siglo XIX" (Zuleta 2000: 85). Dicho texto derivó de la Antología de poetas hispanoamericanos (1893-1895), proyecto encargado a él por la Real Academia Española en 1892, con dos motivos: 1) en honor de la España ultramarina durante la celebración el IV Centenario, 2) para contrarrestar el desconocimiento y desinterés de los españoles por Hispanoamérica y su poesía . En dicha antología Menéndez Pelayo incorporó textos líricos en lengua castellana de poetas ya fallecidos antes de 1892, procedentes de cada una de las regiones del Nuevo mundo descubiertas y civilizadas por los españoles, ya instalados en España. Si bien descartó muestras líricas de Brasil debido al criterio lingüístico de la selección, consideró siempre a este último país partidario de la hispanidad. Su antología fue, pues, como vio Lohmann: "un acto permanente de confraternidad hispanoamericana" (1957: 122); con ella, “imprimió vertebración y cauce al contenido espiritual de la Hispanidad (...) a fin de restablecer la originalidad de la tradición española trasplantada a América" (1957: 177); tradición colonial, caudal de la estirpe, el pensamiento y la capacidad de ensoñación.

En sus advertencias preliminares, aludió a la importancia y trascendencia del latín como lengua de la civilización, el derecho romano, la religión católica $\mathrm{y}$, en consecuencia, pertinente 
para "preparar la unidad espiritual del linaje humano" (Menéndez Pelayo 1948: 6). Destacó las lenguas y dialectos provenientes del latín, primero, en comparación con las lenguas indígenas europeas, extintas muchas durante los procesos de dominación romana, excepto en castas o en comunidades helénicas; $y$, segundo, con respecto a las lenguas, civilización y espíritu germánicos.

Para demostrar la relevancia del castellano como lengua romance de civilización, reconoció desde México hasta Chile a cada uno de los países como seres de la misma lengua, historia y literatura españolas, pese al deseo de algunos por establecer separaciones, frente a lo cual les deseó prosperidad. De todos modos, el hecho de que la Real Academia Española considerara el aporte y valor poéticos de las naciones americanas en una antología conmemorativa de "aquel maravilloso y sobrehumano acontecimiento" (Menéndez Pelayo 1948: 7) evidenció la extensión civilizadora de la lengua castellana y el acercamiento intelectual entre España y estas repúblicas, aún en un contexto de rencores, guerra e incomunicación artística. Se reintegró fraternalmente, pues, en una obra de lengua patria, el culto de los pueblos hispánicos por una misma tradición literaria; se oficializó a los más selectos poetas de cada nación americana dentro de la literatura española y, así, se confirmó la alianza de la raza hispana.

Debido a los intereses anteriores, se excluyó de la antología las producciones precolombinas: "Tratábase sólo de la poesía castellana en América (...) calificada de española en el sentido más tradicional y etnológico de la frase" (Menéndez Pelayo 1948: 9). Al afirmar que prescindiría "de la poesía indígena en lenguas americanas, anterior o posterior a la conquista" (1948: 9), debido a lo incógnito, revesado y extraño que eran para un español, Menéndez Pelayo agregó un rasgo más a su criterio de hispanidad: los salvajes y bárbaros amerindios no eran parte del ser hispánico, pues no compartían la civilización ni por lengua ni por religión, "Sea cual fuere la antigüedad y el valor de los pocos y oscuros fragmentos literarios que de esas lenguas [y comunidades] primitivas qued[e]n" (1948: 10). Solo reunió, por ende, la lírica americana seguidora de la tradición española y la civilización latina:

partiendo del clasicismo italiano del siglo XVI, del culteranismo del XVII, de la reacción neoclásica del XVIII, del romanticismo del presente y de las influencias de la novísima literatura extranjera, especialmente la francesa y de la inglesa [...nunca...] opacas, incoherentes y misteriosas tradiciones de gentes bárbaras o degeneradas, que para los mismos americanos de hoy resultan mucho más extrañas, menos familiares y menos interesantes que las de los asirios, los persas o los egipcios (Menéndez Pelayo 1948: 10).

El aserto anterior confirma su pensamiento de que, además de esta literatura, solo era parte de la hispanidad el pasado americano producido por españoles, criollos y mestizos, desde la Conquista hasta las guerras independentistas y las discordias civiles.

Por otra parte, repudió, tanto en la literatura como en el modo de ser hispanoamericanos, la influencia de la política, literatura, moda, ciencia, arte y cosmopolitismo franceses; la industria mercantil anglosajona y alemana; el protestantismo y las corrientes demográficas italianas. Temió que los caminos de la cultura americana se torcieran y apropiaran de lo pintoresco y postizo y, en consecuencia, declinara el prestigio ascensional de lo hispánico, ya que en todo momento, en España y América: "La Hispanidad, por su misma esencia de imperio espiritual, deb[ía] proyectar su gravitación aun sobre aquellas naciones que se encuentren accidentalmente afectas a la órbita política de naciones extrañas" (Lohmann 1957: 213).

En resolución, al compilar la Antología de poetas hispano-americanos y la Historia de la poesía hispano-americana, Menéndez Pelayo institucionalizó la idea de hispanidad como "espíritu de fraternidad" (1948: 14), de integración ("Al fin son carne de nuestra carne y huesos de nuestros huesos", 1948: 4) y alianza de las naciones de la raza hispana, en virtud de la extensión de su lengua castellana, religión católica, derecho romano y civilización latina, homenajeadas implícitamente en las conmemoraciones del IV Centenario. Desde 
su punto de vista, la hispanidad otorgaba a Hispanoamérica "resonancias ecuménicas, en vez de ecos domésticos" (Lohmann 1957: 45); la oponía a los pueblos salvajes y bárbaros tanto de Europa como de la América precolombina. Para él, pues, "lo peninsular y lo americano era todo uno; sus principios esenciales, comunes, y la interdependencia un hecho irrevocable. América era la prolongación vital de España" (Lohmann 1957: 95-96); la extensión, tradición y posibilidad de la vida hispánica.

\subsection{Juan Valera}

Valera comenzó a publicar sus artículos en 1888. En ellos, presentó a escritores hispanoamericanos (incluido Darío), expresó ideas retomadas luego en sus cartas y fue uno de los primeros en hablar sobre la celebración del IV Centenario del Descubrimiento de América. En su papel de crítico, periodista y ensayista, Valera proporcionó, como Darío, "una imagen nueva próxima a la Hispanidad" (Hernández 2012: 832).

Especialmente, en sus Cartas americanas (1889), Nuevas cartas americanas (1890) y Ecos argentinos (1901), defendió persistentemente la idea de unidad superior que la sangre, lengua, literatura y cultura daban a las naciones hispanoamericanas y su propia personalidad entendida como prolongación de la cultura hispánica en esas otras tierras, a pesar de la independencia política (nótese sintonía con las ideas de Menéndez Pelayo 1948). A manera de ilustración, léanse sus palabras dirigidas al presidente de Ecuador, Antonio Flores:

La unidad de civilización y de lengua, y en gran parte de raza también, persiste en España y en esas Repúblicas de América, á pesar de su emancipación é independencia de la metrópoli. Cuanto se escribe en español en ambos mundos es literatura española, y, á mi ver, al tratar yo de ella, propendo á mantener y á estrechar el lazo de cierta superior y amplia nacionalidad que nos une á todos [sic] (Valera 1890: V).

En su opinión, el hecho de que tales repúblicas consideraran su propia personalidad como extensión de la hispana les permitía participar de un conjunto universal de naciones, casi como una polis helénica. Al respecto escribió:

Si nuestro pueblo, nación, casta, raza o como queramos llamarle, valiéndonos de término más comprensivo, tiene el ser y el brío que yo quiero que tenga, no sólo debe haber elevado a su altura a los indios americanos, confundiéndose y combinándose con ellos, sino que debe también, a pesar de la corrientes, por impetuosa y crecida que sea, de la emigración de otras ramas de Europa conservar el sello, el carácter primitivo, la marca indeleble de su españolismo. Yo quiero que tenga, y si el amor de casta o de raza no me engaña, creo que ha de seguir teniendo el elemento español que hay en América desde Tejas a California hasta el Estrecho de Magallanes, la plasmante virtud que identifique los otros elementos que se le unan (Valera 1944: 14-15).

Al lado de los versos de Darío, la idea de Valera sobre la fusión de los auténticos elementos integradores de Hispanoamérica, regidos y asegurados por la fuerza y persistencia unitivas de lo hispánico, inició el concepto de mestizaje (Zuleta 2000).

Por otro lado, al considerar a Hispanoamérica estrictamente una provincia de las letras españolas, debido a la lengua, tradiciones de estilo y pensamiento, llegó a juzgar los afrancesamientos literarios (de Darío, por ejemplo) y abrir las discusiones sobre el nombre apropiado para referirse a la realidad histórica de América. La expresión "América española" fue usada en 1853 por la Revista Española de Ambos Mundos (Marías 1992). En esta, paradójicamente, apareció un artículo de Michel Chevalier, en el cual se insistía en "lo latino", "lo germánico" y "lo eslavo" tanto de Europa meridional como de América del Sur. A partir de 1861, Chevalier, en la Revue des Races Latines, empleó y siguió utilizando la denominación “"América Latina' para preparar la justificación de que Francia interviniese decisivamente en un país de la América hispánica" (Marías 1992: 88). En la poesía de Darío se encuentra notoriamente el nombre "América española". Por motivo de la crisis del 98 y el debate de la superioridad de los anglosajones sobre los latinos, tanto en España como en los otros países latinos, se 
"revivió el interés por las naciones de allende el mar, uniéndose el concepto de hispanidad al de latinidad" (Litvak 1980: 75), como ocurre en la poesía dariana.

Por su parte, Valera (1890), en un momento inicial, prefirió el calificativo "español" o "ibérico" frente a "latino", en el cual observó cierto desdén por la sangre y el ser (Marías 1992). En 1897, dudó si llamar "latinoamericanas" o "hispanoamericanas" a las naciones trasatlánticas; finalmente, se inclinó por el segundo adjetivo, porque América era obra española y no latina (Litvak 1980). Consideró, además, que la dicotomía entre raza latina y razas germánicas y eslavas era solo un medio creador de odios y rivalidades. En 1902, mostró optimismo por la raza latina e invitó a que se afianzaran las relaciones con la América española, Portugal, Brasil y Cataluña, dado que: "Es así, en bloque, como España debería unirse a la comunidad latina" (citado en Litvak 1980: 51).

En fin, Valera $(1890,1944)$, defendiendo el lugar de España y lo hispánico en América, añadió a la idea de hispanidad el concepto de prolongación de la realidad histórica y personalidad hispánicas en las repúblicas americanas, sin desnaturalizar su propia identidad mestiza ni la herencia común que las volvía universales; es decir, la unidad de sangre, lenguaje y cultura.

\subsection{Rafael Altamira}

En 1898, fue "el primero que demostró que la historia de España era ininteligible sin la de América y que los españoles e hispanoamericanos compartían sentimientos y valores especificados en lo que llamó 'modalidad hispánica"' (Hernández 2012: 835); id est, el intercambio de ideales sin desnaturalizar el parentesco con España, en lo que se ve un claro eco del pensamiento de Valera. Por eso, sugirió y animó proyectos y programas de acción de España en América, apelando a la unidad psicológica del pueblo hispánico antes que al concepto de raza: demostró que en España existía una población diversa, como no había otra en Europa; por lo tanto, resultaba inapropiado hablar de raza; proclamó, en contrarrespuesta, la unidad psicológica del pueblo hispánico, salvación ante la decadencia (Altamira 1902). Asimismo, llamó a la conservación de la comunidad lingüística del castellano en América, la fraternidad y comercio intelectuales; todas estas deberían de ser las verdaderas bases de la política americanista de España, con el fin de robustecerse con la aportación de las naciones americanas (Altamira 1898, 1900, 1902). Analizó, además, la amenaza cultural del sajonismo de Estados Unidos para los países hispanoamericanos (Altamira 1900).

La noción de intercambio intelectual con Hispanoamérica se escuchaba en 1898 tanto en sus palabras como en las reflexiones de Gavinet (2004). Este último abogaba por la creación y reforzamiento de una comunidad cultural e intelectual, donde el conocimiento fuera recíproco y se dieran a conocer los valores literarios hispanoamericanos, allende los intereses de propiedades intelectuales. Por eso, más que una confederación política, Gavinet apeló por una intelectual y espiritual , en que se incluían España, Portugal y las repúblicas americanas, componentes de raza hispánica y católica.

Particularmente, en su discurso de apertura de la Universidad de Oviedo, Altamira (1898) expuso y demandó el papel social remediador de la universidad, el patriotismo y la vida científica española. Divulgó tales ideales desde su posición de catedrático en Oviedo, así como en universidades de Cuba, Uruguay, Chile, Argentina, Perú y México. Su objetivo, cultural más que político, era consolidar intercambios científicos y académicos con organismos hispanoamericanos. De ahí que, en el Congreso Literario Hispanoamericano de 1900, impulsó a que la Universidad de Oviedo presentara una ponencia titulada: "Proposiciones", en que se discutieron como orientación práctica del hispanoamericanismo:

\footnotetext{
la aceptación de los tribunales de arbitraje para los conflictos internacionales, la igualdad jurídica y civil entre todos los ciudadanos hispanoamericanos, el establecimiento de un cable directo entre España y América, la garantía de la propiedad intelectual, la rebaja en el precio de los libros, el proteccionismo del comercio hispanoamericano, el resguardo de los derechos obreros, la creación de un instituto para
} 
maestros, el intercambio de profesores universitarios, la reciprocidad de títulos profesionales, la creación de cátedras destinadas a historia, geografía e instituciones jurídicas y políticas de los países hispanoamericanos, la organización del intercambio de publicaciones, etcétera (Zuleta 2000: 105).

Por su labor pedagógica y filosófica, pues, promovió que esta universidad fuera la primera en preocuparse por un programa de relaciones culturales con Hispanoamérica y que, en 1943, dicha institución abriera la especialidad de Historia de América y luego Antropología Americana (Zuleta 2000, Hernández 2012).

En definitiva, Altamira (1898, 1900, 1902) aportó a la idea de hispanidad el concepto de modalidad hispánica, respondiendo a la unidad psicológica, cultural, científica, pedagógica, lingüística e intelectual, sobre las razones políticas.

\subsection{Miguel de Unamuno}

El interés de Unamuno por Hispanoamérica creció a medida que gradualmente fue identificando "las características que distinguían a España de sus vecinos europeos" (Roberts 2004: 63). Para él, España e Hispanoamérica formaban una comunidad de naciones étnica y políticamente disímiles, cuyo carácter histórico y cultural se debía a la unidad, igualdad, justicia y universalidad de su patrimonio espiritual hispánico, basado esencialmente en la lengua española (nótense los ecos del pensamiento de Menéndez Pelayo sobre la unidad espiritual de España, procedente del derecho y la civilización romanos). Unamuno llamó a esta comunidad, en 1909, hispanidad.

Se quejó, por consiguiente, del desinterés de los españoles sobre temas americanos, aun cuando España debía encontrar respuestas y aliento para sí en sus antiguas colonias: "Ahora que, empequeñecida y acongojada, España busca sus hijas, es cuando necesitamos que nos descubran el campo y la vida de aquellos vivaces retoños de nuestro linaje" (Unamuno 1968: 722). Coincidió en este sentido con Darío y Altamira. Por ello, se acercó a las realidades sociopolíticas y espirituales de Hispanoamérica, a través de sus figuras históricas y literarias; se aprovechó de las columnas de diarios americanos para dictar cátedra al respecto entre 1899 y 1935, y solicitar colaboración, participación e igualdad entre tales pueblos. De ahí que en 1905, quizá con ecos de Altamira y Gavinet, escribió: "Tenemos que acabar de perder los españoles todo lo que se encierra en eso de la madre patria y comprender que para salvar la cultura hispánica nos es preciso entrar a trabajarla de par con los pueblos americanos y recibiendo de ellos, no sólo dándoles" (Unamuno 1968: 97).

No obstante, frente a lo sociopolítico e histórico, la lengua española constituía según él decisivamente la hispanidad. Enfáticamente , defendió que el castellano era el elemento fundante y aunador de la ética y religión del ser hispánico pues, más que acatar una función meramente comunicativa, era depósito de las esencias íntimas, dinámicas y enriquecedoras del pueblo español, portugués e hispanoamericano. Aclárese que Unamuno nunca habló sobre una raza hispánica, ya que desestimó la obsesión colonialista de la época por este concepto (Álvarez 1950, Roberts 2004). Por ende, valoró los aportes lingüísticos de cada una de las repúblicas a la lengua española, ya que no debía existir una variedad dialectal monopolizada (Unamuno 1968). Sobre este último punto dijo: "La cuestión es que los argentinos y todos los demás pueblos de habla española reivindiquen su derecho a influir en el proceso de la lengua común española, tanto como los españoles mismos; que no reconozcan en esto patronato alguno de heredad; que afirmen su manera de entender y sentir el idioma de Cervantes" (Unamuno 1996: 154-155).

Pese al reiterado enfoque lingüístico en sus artículos americanos, también se preocupó por los temas y producciones literarios hispanoamericanos y por darlos a conocer en España. Con este objetivo publicó su primer artículo sobre la poesía gauchesca y el poema Martín Fierro, el 01 de marzo de 1894 en la Revista Española, así como su crítica "De literatura hispanoamericana", en la revista La Lectura en enero de 1901 (Álvarez 1950, Celma 1991, 
Zuleta 2000, Roberts 2004, Hernández 2012). Como Menéndez Pelayo, exaltó la continuación de la tradición literaria española. Aprovechó, igualmente, para criticar el europeísmo, el sajonismo, el cosmopolitismo francés, y la insistencia de literatos hispanoamericanos por reconocer orígenes y valores franceses o italianos en igual o mayor proporción a lo hispánico. Esto es, justamente, cuanto le recriminó Unamuno en su correspondencia a Darío (Amoretti 2010).

Unamuno (1968, 1996), en resumen, sin quedarse en el mero factor lingüístico, señaló la lengua española como la decisiva fuerza constitutiva de la unidad espiritual, literaria, sociopolítica e histórica entre España e América; gracias a esta lengua, la hispanidad debía entenderse como el intercambio fraterno, el interés y el conocimiento mutuos.

\section{A manera de colofón: Situación a finales del siglo XIX}

Con base en lo expuesto, se demuestra cómo, desde las relaciones comunitarias (políticas, económicas, sociales y culturales) del siglo XIX entre España y las repúblicas hispanoamericanas, pese a la pérdida de Cuba en 1898, "nunca se perdió la idea de América como proyección histórico-cultural de España, sobre la base de la asimilación antropológica, la lengua, las creencias comunes y la pervivencia de un pasado común" (Hernández 2012: 830).

El siguiente cuadro permite una visión detallada de los conceptos con que Darío (1950, 2003, 2007), Menéndez Pelayo (1948), Valera (1890, 1944), Altamira (1898, 1900, 1902) y Unamuno $(1968,1996)$ promovieron la idea de hispanidad a finales del siglo XIX.

\section{CUADRO 1}

Conceptos inclusos en la idea de hispanidad de acuerdo con Rubén Darío, Marcelino Menéndez Pelayo, Juan Valera, Rafael Altamira y Miguel de Unamuno

\begin{tabular}{|c|c|c|c|c|c|}
\hline Aspecto de la hispanidad & Darío & Menéndez Pelayo & Valera & Altamira & Unamuno \\
\hline Idealismo espiritual & $\sqrt{ }$ & $\mathrm{X}$ & $\mathrm{X}$ & $\mathrm{X}$ & $\mathrm{X}$ \\
\hline Modo de ser hispánico & $\begin{array}{l}\text { Lo caballeresco, } \\
\text { noble, heroico, } \\
\text { católico y } \\
\text { castellano }\end{array}$ & $\begin{array}{l}\text { Lo católico, } \\
\text { castellano y } \\
\text { latino, el derecho } \\
\text { romano }\end{array}$ & $\mathrm{X}$ & $\begin{array}{l}\text { Unidad } \\
\text { psicobiológica }\end{array}$ & $\mathrm{X}$ \\
\hline Valor de universalidad & $\sqrt{ }$ & $\sqrt{ }$ & $\sqrt{ }$ & $\mathrm{X}$ & $\sqrt{ }$ \\
\hline $\begin{array}{l}\text { Unidad sobre la base de la herencia } \\
\text { lingüística, reli-giosa y cultural del } \\
\text { Imperio español }\end{array}$ & $\sqrt{ }$ & $\sqrt{ }$ & $\sqrt{ }$ & $\sqrt{ }$ & $\sqrt{ }$ \\
\hline Raza & $\begin{array}{l}\text { Hispánica } \\
\text { y latina }\end{array}$ & $\begin{array}{l}\text { Hispánica } \\
\text { y latina }\end{array}$ & $\begin{array}{l}\text { Hispánica o } \\
\text { ibérica }\end{array}$ & $\mathrm{X}$ & $\mathrm{X}$ \\
\hline $\begin{array}{l}\text { Inclusión de lo prerromano } \\
\text { (celta, ibero, griego, fe-nicio, } \\
\text { cartaginés...) }\end{array}$ & Griego & $\sqrt{ }$ & $\mathrm{X}$ & $\sqrt{ }$ & $X$ \\
\hline Inclusión de lo visigótico & $\mathrm{X}$ & $\sqrt{ }$ & $X$ & $\mathrm{X}$ & $X$ \\
\hline Inclusión de lo romano & $\sqrt{ }$ & $\sqrt{ }$ & $\sqrt{ }$ & $\sqrt{ }$ & $\sqrt{ }$ \\
\hline Inclusión de lo musulmán y judío & $\sqrt{ }$ & $\mathrm{X}$ & $\mathrm{X}$ & $\sqrt{ }$ & $\mathrm{X}$ \\
\hline Inclusión de lo lusitano & $\mathrm{X}$ & $\sqrt{ }$ & $\sqrt{ }$ & $\sqrt{ }$ & $\sqrt{ }$ \\
\hline $\begin{array}{l}\text { Inclusión de lo precolombino y } \\
\text { mestizo americano }\end{array}$ & $\sqrt{ }$ & $X$ & $\sqrt{ }$ & $\sqrt{ }$ & $\mathrm{X}$ \\
\hline Inclusión de lo filipino & $\mathrm{X}$ & $\mathrm{X}$ & $\mathrm{X}$ & $\mathrm{X}$ & $\mathrm{X}$ \\
\hline
\end{tabular}




\begin{tabular}{|c|c|c|c|c|c|}
\hline Visión nacionalista & $\mathrm{X}$ & $\sqrt{ }$ & $\mathrm{X}$ & $\mathrm{X}$ & $\mathrm{X}$ \\
\hline Visión política & $\mathrm{X}$ & $\mathrm{x}$ & $\mathrm{X}$ & $\mathrm{x}$ & $\mathrm{X}$ \\
\hline $\begin{array}{l}\text { España como amparo y orientación } \\
\text { espiritual, civilizadora y ética para } \\
\text { las naciones americanas }\end{array}$ & $\sqrt{ }$ & $\sqrt{ }$ & $\mathrm{x}$ & $\mathrm{x}$ & $\mathrm{X}$ \\
\hline $\begin{array}{l}\text { Repúblicas hispanoamericanas } \\
\text { (pese a ser independientes) como } \\
\text { prolongación de España }\end{array}$ & $\mathrm{x}$ & $\sqrt{ }$ & $\sqrt{ }$ & $\mathrm{X}$ & $\sqrt{ }$ \\
\hline Fraternidad & $\sqrt{ }$ & $\sqrt{ }$ & $\sqrt{ }$ & $\sqrt{ }$ & $\sqrt{ }$ \\
\hline $\begin{array}{l}\text { Intercambios literarios, } \\
\text { intelectuales, artísticos y } \\
\text { culturales }\end{array}$ & $\sqrt{ }$ & $\sqrt{ }$ & $\sqrt{ }$ & $\sqrt{ }$ & $\sqrt{ }$ \\
\hline $\begin{array}{l}\text { Oposición a los ideales } \\
\text { materialistas y religiosos del } \\
\text { (anglo)sajonismo y germanismo }\end{array}$ & $\sqrt{ }$ & $\sqrt{ }$ & $\sqrt{ }$ & $\mathrm{x}$ & $\sqrt{ }$ \\
\hline Oposición a lo francés o italiano & $\mathrm{X}$ & $\sqrt{ }$ & $\sqrt{ }$ & $\mathrm{X}$ & $\sqrt{ }$ \\
\hline
\end{tabular}

Según el pensamiento de estos autores, la hispanidad supone un valor de universalidad que permite la unidad de España y las repúblicas independientes de América con base en la lengua española, la religión católica y la cultura heredada del período imperial. El concepto de raza, debido a los discursos de mitad de siglo, pesa en la conformación de una modalidad de ser hispánico, considerando componentes culturales y simbólicos de diferentes grupos étnicos, principalmente los latinos, los ibéricos posteriores al siglo III, los precolombinos y mestizos americanos. El sentimiento de fraternidad también se ve implicado y contribuye con los intercambios literarios, culturales, artísticos e intelectuales.

Considérese, específicamente, que gracias a estos escritores y pensadores, desde el principio la literatura ha sido el medio fundamental para la expresión crítica de la hispanidad, más allá de la mera preocupación por los factores lingüísticos y las tradiciones estéticas.

Gracias a los aportes filosóficos y literarios de Darío, Menéndez Pelayo, Valera, Altamira y Unamuno, se puede afirmar que: "La construcción de la Hispanidad es obra mutua de españoles e hispanoamericanos que han conseguido, mediante esfuerzos e intenciones individuales, llegar a cristalizar un resultado coherente, racional, de sentimientos afectivos no exentos de crítica, en definitiva, caminos de comunicación hasta la construcción del edificio de esta identidad, utilizando los cimientos nada despreciables de una comunidad vital, social e ideal de más de tres siglos" (Hernández 2012: 830).

\section{Notas}

1 En relación con la herencia musulmana, por ejemplo, canta en dos momentos: "Sire de ojos azules, gracias: por los laureles/ De cien bravos vestidos de honor; por los claveles/ De la tierra andaluza y la Alhambra del moro; Por la sangre solar de una raza de oro" (Darío 2007: 251) y "En los sepulcros musulmanes, una/ copa remata la obra; el agua fina/ de la urna matinal, y la argentina/ perla que da a su ánfora la luna” (Darío 2007: 1115). En el poema "Sefardí", desprecia los prejuicios contra los hispano-judíos y ensalza su contribución a la España medieval e imperial: " ¡Benditos seáis los odiados,/ los tremebundos maldecidos,/ los eternos vencidos y eternos desterrados, / en pasajeras cuevas y trashumantes nidos!// ¡Benditos, oh judíos, desterrados de España!// Dueños del oro y del trabajo,/ fuisteis los proveedores de ruecas e incensarios;/ os pidieron favores los hidalgos precarios,/ dominasteis arriba y ayudasteis abajo" (Darío 2007: 1216).

2 "Si en estos cantos hay política, es porque aparece universal. Y si encontráis versos a un presidente, es porque son un clamor continental. Mañana podremos ser yanquis (y es lo más probable); de 
todas maneras, mi protesta queda escrita sobre las alas de los inmaculados cisnes, tan ilustres como Júpiter" (Darío 2007: 244).

A propósito del racismo estadounidense escribió: "No, no puedo, no quiero estar de parte de esos búfalos de dientes de plata. Son enemigos míos, son los aborrecedores de la sangre latina, son los Bárbaros. (...) Colorados, pesados, groseros, van por sus calles empujándose y rozándose animalmente, a la caza del dollar [sic]. El ideal de esos calibanes está circunscrito a la bolsa y a la fábrica. Comen, comen, calculan, beben whisky y hacen millones. Cantan ¡Home, sweet home! Y su hogar es una cuenta corriente, un banjo, un negro y una pipa" (Darío 2003: §§1-2). En relación con la ausencia del catolicismo, se refirió a Roosevelt como sinécdoque de los Estados Unidos: "(Eres un Profesor de energía/ Como dicen los locos de hoy.)/ Crees que la vida es incendio,/ Que el progreso es erupción;/ Que en donde pones la bala/ El porvenir pones./ No./ Los Estados Unidos son potentes y grandes. (...) Juntáis al culto de Hércules el culto de Mammón;/ Y alumbrando el camino de la fácil conquista,/ La Libertad levanta su antorcha en Nueva York. (...) Y, pues contáis con todo, falta una cosa: ¡Dios!” (Darío 2007: 258-259).

"Mas la América nuestra (...)/ Que ha guardado las huellas de los pies del gran Baco,/ (...) Que consultó los astros, que conoció la Atlántida/ Cuyo nombre nos llega resonando en Platón,/ Que desde los remotos momentos de su vida/ Vive de luz, de fuego, de perfume, de amor,/ La América del grande Moctezuma, del Inca,/ La América fragante de Cristóbal Colón,/ La América católica, la América española" (Darío 2007: 259)

Al respecto podría interpretarse los versos: "Ya veréis el salir del sol en un triunfo de liras,/ Mientras dos continentes, abonados de huesos gloriosos,/ Del Hércules antiguo la gran sombra soberbia evocando,/ Digan al orbe: la alta virtud resucita/ Que a la hispana progenie hizo dueña de siglos" (Darío 2007: 249).

En 1892, para la celebración del IV centenario, Darío publicó, en una revista española (Salinas 1975), el poema "A Colón", en el cual lo exaltó, pero con pesimismo, dureza e invectivas. Dicen la primera y última estrofas: “Desgraciado Almirante! Tu pobre América,/ tu india virgen y hermosa de sangre cálida,/ la perla de tus sueños, es una histérica/ de convulsivos nervios y frente pálida. (...) Duelos, espantos, guerras, fiebre constante/ en nuestra senda ha puesto la suerte triste:/ ¡Cristóforo Colombo, pobre Almirante,/ ruega a Dios por el mundo que descubriste!" (Darío 2007: 332-333).

7 "Hablando [Darío] de Cantos de vida y esperanza, dice: 'Hay mucho hispanismo en este libro mío... ¡Hispania por siempre!”” (Salinas 1975: 41)

Menéndez Pelayo le comentó este asunto a Miguel Antonio Caro en una carta en 1878. Por eso, escribió en "Al lector": "esta obra es, de todas las mías, la menos conocida en España, donde el estudio formal de las cosas de América interesa a muy poca gente a pesar de las vanas apariencias de discursos teatrales y banquetes de confraternidad" (1948: 4).

"Acaso más adelante me anime a completarla con el tratado de la poesía portuguesa en el Brasil, para que la obra merezca con toda propiedad el título de Historia de la poesía hispano-americana." (Menéndez Pelayo 1948: 3)

Debido a que algunos poetas no se formaron dentro de la escuela académica y se hicieron pasar por "aztecas, guaraníes y araucanos" (Menéndez Pelayo 1948: 11), es posible que "algo del americanismo primitivo llegó a infiltrarse en esta poesía (lo cual es muy dudoso), sólo en este sentido podrán tener cabida tales elementos bárbaros y exóticos en un cuadro de la literatura hispano-americana" (1948: 10).

Menéndez Pelayo (1965) observó que las guerras entre los españoles e ingleses siempre habían tenido un carácter de luchas religiosas entre el catolicismo y el protestantismo. Esto lo condujo a redactar su Historia de los heterodoxos (1880-1882).

Zuleta (2000) y Hernández (2012) las fechan en 1900. Dicha discrepancia no ha motivado polémica.

"La América del Sur es como la Europa Meridional católica y latina, y la del Norte pertenece a una población protestante y anglosajona." (Chevalier, 1853, cit. en Marías 1992: 88)

Al respecto dijo Gavinet: "no queda, pues, otra confederación posible que la 'Confederación intelectual o espiritual', y ésta exige: primero, que nosotros tengamos ideas propias para imprimir unidad a la obra; y segundo, que las demos gratuitamente, para facilitar su propagación" (2004: 87). 
Advirtió Gavinet sobre la raza y religión árabes, por ejemplo: "la toma de Granada y la terminación de la reconquista no podía ser el último golpe contra los moros: entonces estaba aún pujante el poder musulmán y debía de temerse una nueva acometida, pues el mahometismo lleva en sí un germen de violencia que hoy parece extinguido y mañana reaparece encarnado en un pueblo más joven que de nuevo le da calor y vida" (2004: 65).

Prueba de ello son estas palabras dirigidas al director del periódico argentino El Mundo Latino, en 1905: "Usted sabe que en la mayor parte de las redacciones de nuestros grandes diarios van los periódicos americanos al cesto de los papeles sin siquiera romperles la faja; usted sabe que los más de los españoles que se tienen a sí mismos por cultos y pasan entre las gentes por tales, ignoran los límites de Bolivia, hacia dónde cae el Paraguay y si la República del Salvador da al Atlántico o al Pacífico; usted sabe que apenas se lee aquí libros americanos, a pesar de los esfuerzos que hacemos algunos escritores por darlos a conocer" (1996: 206).

Escribió en 1899 en el periódico bonaerense El Sol: "ahora es cuando nos acordamos de nuestra raza. Nuestra unidad es, o más bien será, la lengua, el viejo romance castellano convertido en la gran lengua española, sangre que puede más que el agua, verbo que domina el Océano" (1968: 571). En 1907, en Sobre la literatura hispanoamericana afirmó: "La lengua es la sangre del espíritu; se piensa con palabras y todo aquel que piense desde niño en español pensará a la española, créalo o no, sépalo o no lo sepa, y aunque no corra ni una sola gota de sangre española en sus venas. La lengua es la sangre del espíritu social y así como la sangre es el ambiente interior del cuerpo, así la lengua es el ambiente interior del espíritu colectivo, el vehículo de su nutrición ideal" (1968: 911). En 1911, en Rosario de sonetos líricos reiteró: "La sangre de mi espíritu es mi lengua/ y mi patria es allí donde resuene/ soberano su verbo, que no amengua/ su voz por mucho que ambos mundos llene" (1968: 568).

\section{Referencias bibliográficas}

Acereda, Alberto. 2000. La hispanidad amenazada. Rubén Darío y la guerra del 98. Bilingual Review. 25 (1): 99-110.

Allen, David. 1967. Rubén Darío frente a la creciente influencia de los Estados Unidos. Revista Iberoamericana, Homenaje a Rubén Darío. Julio-diciembre: 387-393.

Altamira, Rafael. 1898. El patriotismo y la Universidad. Boletín de la Institución Libre de Enseñanza. 22: 257-270, 291-296 y 323-327.

1900. Cuestiones Hispano-americanas. Madrid: Rodríguez Serra.

1902. Psicología del pueblo español. Madrid: Biblioteca Nueva.

Alvar, Manuel. 1999. Del modernismo a la generación del 98. En: Laín Entralgo, coord.: 45-106.

Álvarez, Ángel. 1950. El pensamiento de Unamuno sobre Hispanoamérica. Madrid: Cuadernos Hispanoamericanos.

Álvarez, José. 2002. La conformación de una identidad. En: Gómez-Ferrer, coord.: 5-45.

Álvarez, Rafael. 1895. El porvenir de la raza. Revista Contemporánea. Julio-septiembre: 355-367.

Amoretti, María. 2010. Interculturalidad y mestizaje en Rubén Darío. En: Chen, ed.: 25-80.

Balmes, Jaime. 1925. El protestantismo comparado con el catolicismo en sus relaciones con la civilización europea. Barcelona: Biblioteca Balmes. 
Bueno, Gustavo. 2001. España y América. En: Catauro. Recuperado de http://www. filosofia.org/aut/gbm/200 1eya.htm

Celma, Pilar. 1991. Literatura y periodismo en las revistas del fin de siglo. Estudio e indices. Madrid: Júcar.

Chávez, Julio. 1966. Unamuno y América. Madrid: Cultura Hispánica.

Chen, Jorge. 2010. Asedios posmodernos a Rubén Darío. León, Nicaragua: UNAM.

Darío, Rubén. 1950. España contemporánea. Madrid: Biblioteca Rubén Darío.

.2003. El triunfo de Calibán. Recuperado de http://www.biblioteca.org.ar/ libros/155.pdf.

. 2007. Poesías. Obras completas I. Barcelona: Galaxia Gutenberg.

Departamento de Letras de la Universidad Nacional de La Plata. 1968. Rubén Darío (Estudios reunidos en conmemoración del centenario 1867-1967). Argentina: Universidad Nacional de La Plata.

Fernández, Melchor. 1957. La emancipación de América y su reflejo en la conciencia española. Madrid: Instituto de Estudios Políticos.

Forgelquist, Donald. 1958. Españoles de América y americanos de España. Madrid: C.S.J.C.

Forment, Eudaldo. 2008. Prólogo. En: García Morente: 7-77.

García Morente, Manuel. 2008. Idea de la hispanidad. Madrid: Homolegens.
Gavinet, Ángel. 2004. Idearium español. El porvenir de España. Madrid: Idea y Creación.

Giménez Caballero, Ernesto. 1963. Lengua y literatura de la hispanidad. Los orígenes. Madrid: Talleres tipográficos de Ernesto Giménez Caballero.

1965. Lengua y literatura de la hispanidad. Ilustración, romanticismo, hispanidad. Madrid: Talleres tipográficos de Ernesto Giménez Caballero.

Gomá, Isidro de. 1934. Apología de la hispanidad. Conferencias pronunciadas en Buenos Aires, 12 de octubre de 1934. Recuperado de http://hispanidad.tripod.com/goma.htm

Gómez-Ferrer, Guadalupe. 2002. Historia de España Menéndez Pidal. La época de la Restauración (1875-1902). 36 (2). Madrid: Espasa Calpe.

Hernández, Mario. 2012. América española. Historia e identidad de un mundo nuevo. Madrid: Trébede.

Hurtado, Julián. 2001. Las invasiones bárbaras. Recuperado de http://www. arturosoriacom/historia/art/bar baros.asp.

Jackson, Richard. 1967. La presencia negra en la obra de Rubén Darío. Revista Iberoamericana, Homenaje a Rubén Darío. Julio-diciembre: 395-417.

Juan, Jorge y Antonio de Ulloa. 1918. Noticias secretas de América. Madrid: América.

Kosling, Gustavo. 1955. Por los fueros de la hispanidad. Lima: s.n.

Lago, Antonio. 1997. América en la conciencia española de nuestro tiempo. Madrid: Trotta. 
Laín Entralgo, Pedro. 1999. Historia de España Menéndez Pidal. 39 (2). Madrid: Espasa Calpe.

Lira, Osvaldo. 1952. Hispanidad y mestizaje y otros ensayos. Madrid: Cultura Hispánica.

Litvak, Lily. 1980. Latinos y anglosajones: orígenes de una polémica. Barcelona: Puvill.

Lohmann, Guillermo. 1957. Menéndez Pelayo y la hispanidad. Madrid: Rialp.

Lombardi, Ángel. 1984. América Latina, historia e identidad. Opción. 1 (1): 35-48. Recuperado de http://www.revistas.luz. edu.ve/index.php/op/article/viewFile/3815 13707 .

Maeztu, Ramiro de. 1931. "La Hispanidad". En: Acción Española (15, diciembre): 8-16. Recuperado de http://www.filosofia.org/ hem/193/acc/e01008.htm

1934. Defensa de la hispanidad. Recuperado de http://www.lalegion. pe/Biblioteca/Historia/defensadela hispanidad.pdf

Marías, Julián. 1992. La Corona y la comunidad hispánica de naciones. Madrid: Asociación Francisco López de Gómara.

Mayán, Francisco. 1943. El sino de la hispanidad. Madrid: Enrique Prieto.

Menéndez Pelayo, Marcelino. 1948. Historia de la poesía hispano-americana. Santander: Aldus.

1965. Historia de los heterodoxos españoles. Madrid: BAC.

Montalvo, Juan. 1944. Geometría moral. Buenos Aires: Americalee.
Palenque, Marta. 1990. Gusto poético y difusión literaria en el realismo español. La Ilustración Española y Americana (1869. 1905). Sevilla: Alfar.

Real Academia Española. 2001. Diccionario de la lengua española. Recuperado de http:// lema.rae.es/drae/

Roberts, Stephen. 2004. 'Hispanidad': El desarrollo de una polémica noción en la obra de Unamuno. Cuadernos de la Cátedra Miguel de Unamuno. 39: 61-80.

Rojas, Miguel. 1997. Los cien nombres de América: Eso que descubrió Colón. San José: Universidad de Costa Rica.

Salinas, Pedro. 1975. La poesía de Rubén Darío. Barcelona: Seix Barral.

Suárez, Reina. 1968. Los prólogos de Darío. En: Departamento de Letras de la Universidad Nacional de La Plata: 138-167.

Unamuno, Miguel de. 1968. Obras completas. Madrid: Escélicer.

Epistolario americano (1890-1936). Salamanca: Universidad de Salamanca, 1996.

Valera, Juan. 1890. Nuevas cartas americanas. Madrid: Fernando Fe.

1944. Carta-prólogo. En: Montalvo: 1-51.

Vallejo, Antonio. 1937. Eugenesia de la hispanidad y regeneración de la raza. Burgos: Española.

Van Aken, Mark. 1959. Pan-hispanism. Its Origin and Development to 1866. Barkeley y Los Ángeles: University of California Press. 
Vidart, Luis. 1866. Revistas científicas y libros omitidos. La filosofía española. Madrid: Imprenta Europea. Recuperado de http:// www.filosofia.org/aut/vid/fe16.htm

Vizcarra, Zacarías de. 1944. Origen del nombre, concepto y fiesta de la Hispanidad. El Español. Semanario de la política y del espíritu. 102 (3): 1-13. Recuperado de http://www.filosofia.org/hem/194/ esp/9441007a.htm

Zuleta, Enrique. 2000. España en América. Estudios sobre la historia de las ideas en Hispanoamérica. Buenos Aires: Confluencia.

\section{$\Theta \oplus \Theta \Theta$}


